\section{Coulomb and Structural Engineering}

To mark the bicentenary of the birth of Charles Augustin Coulomb (1736-1806), to which reference was made in Nature of June 13, p. 976, Mr. S. B. Hamilton read to the Newcomen Society on December 16 a paper dealing with his work as a "Pioneer in the Science of Construction". After briefly sketching Coulomb's career, Mr. Hamilton dealt first with Coulomb's paper written in 1773 entitled "Essay on the Application of the Rules of Maxima and Minima to Statical Problems Relating to Architecture". This paper, which has never been published in English, was concerned with beams, piers and arches. Mr. Hamilton then turned to the researches of Coulomb on torsion, and after reviewing the work of Galileo, Mariotte, Hooke, La Hire and many others, he said that Coulomb, in considering the strength of materials, realized that brittle materials subject to crushing failed by shear; that he recognized the truth of Hooke's law and gave it its true place in elastic theory; that his theories of bending and twisting, although incomplete, were a sound contribution to knowledge, and still provide the basis of everyday calculations; that by a stroke of genius he anticipated the modern view that elastic strains are due to distortion of the space lattice within a crystal, while plastic deformation and fracture are due to the development of slip planes; and he also derived a satisfactory simple method of calculating the thrust of earth against retaining walls, and made a sound contribution to the study of masonry arches.

\section{Air Raid Precautions}

The sixth of the handbooks issued by the Air Raid Precautions Department of the Home Office is entitled "Air Raid Precautions in Factories and Business Premises" (London : H.M. Stationery Office, 1936. 6d. net), and is intended primarily for factory occupiers, for occupiers of large commercial premises and other employers of labour, on whom would rest in time of emergency a responsibility for the protection of their employees while at work and the safeguarding of their property. The handbook explains that the air raid precautionary services which are being organized by local authorities all over the country should be supplemented by the individual efforts of householders and of employers of labour. It is suggested that in undertakings employing considerable numbers of workers, a scheme of air raid precautions embracing as many as possible of the services required should be worked out. The importance of close co-operation with the local authority of the area is stressed. Since in the event of air attack it would be impossible to improvise the necessary precautionary measures at short notice, the measures to be adopted should be surveyed at the present time and the necessary plans and preliminary arrangements made for putting them into force without delay. The handbook contains detailed guidance on means of protecting employees against gas, and blast and splinters from high-explosive bombs; the safeguarding of property and material from damage, and arrangements for emergency repair work; first-aid facilities ; the organization of adequate fire-fighting appliances, including special measures to deal with incendiary bombs; decontamination of material affected by persistent gas; provision of emergency communications and steps to ensure the effectiveness of lighting restrictions. Employers of labour are recommended to prepare schemes covering these aspects of air raid precautions and to arrange for their employees to receive training in the duties involved.

\section{Celtic Studies}

Mr. J. M. De Navarro, in his John Rhŷs Memorial Lecture for 1936, delivered before the British Academy on December 17, surveyed the history of research in an early phase of Celtic culture, dealing with the La Tène period of the European Iron Age, in which the Celtic peoples emerged from the half light preceding the dawn of written history. $\mathrm{He}$ pointed out that the geographical extension of the La Tène civilization and its association with Celtic peoples was first determined by Sir Augustus Franks. Subsequent research has tended to confirm his views. No serious contribution to the study of this civilization was made before the fifties and sixties of the last century, when Thurnham, Franks and the German archæologist Lindenschmidt made research possible by assembling various La Tène types into a definite group. The problem was at first approached in the light of literary evidence. Therefore, Mr. de Navarro went on to show, special importance is attached to the typological work in 1885 of Tischler, which resulted in his division of the La Tène period into three phases, and the work five years later of Sir Arthur Evans on the Aylesford urnfield, a con. tribution of which the significance is felt more to-day than it was then. After reference to Reinecke, Déchelette and others, special mention was made in dealing with post-War activities in this field to the work of Jacobsthal, who like Reinecke was a trained classical archæologist. He viewed the La Tène style on its own merits, and not as a mere barbaric reflection of classical art. Finally, in discussing the locality in which the La Tène civilization originated, M. de Navarro expressed himself as in agreement with Déchelette and Dr. R. M. Wheeler in placing it in the region of the rich Early La Tène chieftains' graves of the middle Rhenish area.

\section{Central American Studies: The Copan Project}

DR. A. V. KIDDER, reporting on the work of the Division of Historical Research of the Carnegie Institution, Washington, D.C. (Year Book, Carnegie Institution of Washington, 1935), in Central America during the year 1935, records two additions to the already wide range of subjects embraced in the Institution's scheme of correlated research in the archæology, ethnography, physical anthropology and human ecology of Yucatan and Honduras. The new activities are the Copan Project and the Maize Survey. The Copan Project is a joint undertaking with the Government of Honduras to conserve and 
make available for scientific study and lay observation outstanding examples of the architectural and sculptural art of the ancient Maya. Similar work has already been carried out by the Institution on the temples of Chichen Itza and the stelæ of Quirigua. Copan is a centre in which are the finest products of the art of the Old Empire of the ancient Maya. It has the added interest that not only was it one of the first sites investigated by those pioneers of Central American archæology, Stevens and Catherwood, in the earlier half of the nineteenth century, but it was also the site from which A. P. Maudslay obtained, at his own expense and with immense difficulty and labour, his famous collection of plaster casts of architectural and artistic detail, of which examples are now displayed in the British Museum, after many years of neglect. The operations of the Institution at Copan began in 1935 under Mr. Gustav Stromwik, and have already produced important chronological data relating to pottery found at the base of reconditioned stelae.

\section{The Maize Survey}

Tне Maize Survey has been established by the Institution in co-operation with the United States Department of Agriculture, officers from the Department being seconded for the purpose. The object of the survey is to investigate the origin of maize and to make a study of the maize agronomy of the Maya area. Although maize is the cereal which made possible the rise of pre-Columbian American civilization, its ancestry is problematical and it is not known certainly where and when it was brought under cultivation-a question having an intimate bearing on the beginnings of higher New World culture, including that of the Maya. In reporting on the results of a preliminary survey, which lasted for about a month in the field, Messrs. R. A. Emerson and J. K. Kempton offer certain tentative conclusions, which will serve to throw some light on the density of the ancient population and the relative proportions of the urban and agricultural population. The cultivation of maize, as at present practised, is on the milpa system; that is, a plot, after being burned off, is cultivated for two years, when it is allowed to revert to forest conditions, taking about eight to ten years to become completely re-established and ready for burning off again. Consumption is at an average rate of $1 \cdot 6 \mathrm{lb}$. per head per day, which gives an annual consumption by a family of two adults and three children requiring from three to four acres under cultivation. This is about the amount which the Indians now claim to cultivate. The milpa system is the only system possible in Yucatan, even with modern tools and transport, and may, therefore, be presumed to be that followed by the ancient Maya. There is no evidence that it might not be followed indefinitely. The region, as thus cultivated, is capable of supporting a population of fifty persons per square mile, with ten persons as non-agricultural urban inhabitants. Maize cultivation has now completely supplanted the cotton grown by the ancient Maya, and only a small quantity of tobacco is grown.

\section{New Exhibits in the Museums at Kew}

Throdar the generosity of various firms, the Royal Botanic Gardens, Kew, have recently acquired some additional specimens of general interest to the public. A new set of examples in Museum IV show. ing the various processes in the manufacture of a modern tennis racket has been presented by Messrs. F. H. Ayres, Ltd. The old method of making a tennis racket was to bend a single strip of ash into the required shape, but now a better process has been developed by the use of laminated wood of various kinds. In the modern examples on exhibit, the outer layer is of English oak, the innermost is of ash, and the several ply between are of Canadian birch and English beech with an insertion of walnut. The wedge at the top of the handle is of English sycamore, the top and side clasps are of Malayan lauan, whilst the wedge bend is of Canadian rock elm. A very carefully prepared series of veneers is shown in Museum No. III. The samples shown have been presented by Messrs. John Wright and Sons (Veneers), Ltd., Avon Wharf, Mile End Road, E.3, many of them having been supplied by the firm for the interior decoration of the Queen Mary. The veneers are cut from logs obtained from many parts of the world, some of the species being rare and not even yet known botanically. By very thin cutting in various directions a single tree supplies a great quantity and range of veneers, and very large sheets are obtained by cutting around the tree with a rotary machine. In the same Museum (No. III) new exhibits include a fine series of photographs by Dr. I. B. Pole-Evans, which give a good idea of the flora] regions of South Africa, and alongside are bouquets of some of the beautiful everlasting flowers (mostly Composites) from the same region. These have been sent by Dr. Fourcade, Humansdorp, and Dr. Muir, Riversdale. In the large Indian case at the west end of the building are displayed a series of botanical paintings of Swiss alpine plants by the late Miss Sidney E. Forster and presented by Miss A. E. Pepys in 1934, together with a fine set of coloured postcards of similar subjects from the private collection of the Director.

\section{Degassing' by Electricity}

IN World Power of October an interesting device is described for 'degassing' underground channels, such as sewers, drains and conduits, which has been used successfully abroad. Many large towns have records of street explosions proving the dangers arising from fortuitous concentration of gases such as methane, ether and benzene arising from the greater use of petrols in vehicles and the increasing variety of industrial chemical processes. As a rule, these gases are heavier than air, and become highly explosive when mixed with it. The apparatus consists of a motor-driven centrifugal suction fan. This is connected by suitable tubing to a floating suction head. The heavy gases are collected as nearly as possible at the level of the water at the suction head and pass through the tube with considerable velocity to the fan in the container. The power taken to 